\title{
Somatic embryogenesis in Acrocomia aculeata Jacq. (Lodd.) ex Mart using the thin cell layer technique
}

\author{
João Henrique Delfrate Padilha ${ }^{1 *}$, Luciana Lopes Fortes Ribas², Érika Amano² and Marguerite Quoirin ${ }^{2}$
}

Received: February 11, 2015. Accepted: July 21, 2015

\begin{abstract}
Considering the necessity of Acrocomia aculeata propagation for large-scale production, the aim of this study was to establish a somatic embryogenesis protocol using the thin cell layer (TCL) technique. Aerial parts of in vitro plants were transversally cut at the base into eight TCLs and placed in a culture medium for callus induction. The induction medium was composed of $\mathrm{Y} 3$ salts and Morel's vitamins and supplemented with 150, 300 or $600 \mu \mathrm{M}$ picloram. After 12 weeks the calli were transferred to a medium supplemented with BAP or 2-iP (12.5 or $25 \mu \mathrm{M})$. After 18 weeks, the somatic embryo clusters were transferred to a conversion medium (plant growth regulator-free medium). Primary callus induction rate was higher in the first three TCLs and in media containing 150 or $300 \mu \mathrm{M}$ picloram. The best maturation results were obtained in medium containing $12.5 \mu \mathrm{M} 2$-iP or $12.5 \mu \mathrm{M}$ BAP. Few somatic embryos converted into plants. The histological analyses showed that callus induction started adjacent to vascular bundles after two days of culture, and somatic embryos arose in the periphery of nodular calli. This study showed that the TCL embryogenesis protocol is promising for in vitro multiplication of A. aculeata.
\end{abstract}

Keywords: 2-iP, callus induction, histology, macaw palm, picloram

\section{Introduction}

Acrocomia aculeata is a palm species native to Central and South America. In Brazil the species occurs mainly in the states Minas Gerais, Goiás, Mato Grosso and Mato Grosso do Sul (Scariot et al. 1995), where it is popularly known as bocaiuva or macauba. Its fruits hold great potential for the production of two types of oil, one from the mesocarp and the other from the kernel (Henderson et al. 1995; Lorenzi 2006). The quality of the kernel oil is similar to that of coconut and palm oil; it is used as edible oil and by the pharmaceutical industry (Bélen-Camacho et al. 2005; Hernández et al. 2007). The use of the fruit for oil also generates by-products such as mesocarp cake, which is rich in high-value soluble fibers for use in animal feed and the production of cakes and biscuits (Ramos et al. 2008).

Presently the production of $A$. aculeata is primarily extractive and its propagation done with seeds, which exhibit dormancy and experience a low germination rate (Lorenzi 2006; Ribeiro et al. 2012), although Motoike et al. (2007) developed a method that raised the germination rate to $60-80 \%$. For large-scale commercial use of A. aculeata it is necessary to develop a technique for the clonal propagation in order to establish a uniform cultivation system.
Somatic embryogenesis is the process by which a single cell, or a group of somatic cells, produces somatic embryos - bipolar structures without a vascular connection to the mother tissue (Arnold et al. 2002; Cangahuala-Inocente et al. 2004). This system is similar to zygotic embryogenesis and is comprised of several steps starting with embryogenic cell formation, followed by differentiation into a somatic embryo, and then maturation and conversion into a plant (Ammirato 1983; Arnold et al. 2002).

Somatic embryogenesis holds promise as a technique for palm tree propagation, especially when other propagation techniques prove too difficult or are unviable (Sané et al. 2006; Steinmacher et al. 2007c). It can be induced in different types of explants, such as zygotic embryos, inflorescences, shoot tips and immature leaves, and may allow the production of many identical plants (Steinmacher et al. $2007 \mathrm{a} ; \mathrm{b})$.

The thin cell layer technique (TCL) consists of cultivating small explants excised (longitudinally or transversely) from different organs (Tran Than Van 1973). The TCL culture may induce specific morphogenic routes, such as controlled somatic embryo production (Nhut et al. 2003). The technique has proven efficient at propagating many plant species (Silva et al. 2007; Silva 2010) and, among palm

\footnotetext{
${ }^{1}$ Departamento de Fitotecnia e Fitossanitarismo, Setor de Ciências Agrárias, Universidade Federal do Paraná, 81531-980, Curitiba, PR, Brazil ${ }^{2}$ Departamento de Botânica, Setor de Ciências Biológicas, Universidade Federal do Paraná. P.O. Box 19031, Jardim das Américas, 81531-980 Curitiba, PR, Brazil

*Corresponding author: joaodelfrate@gmail.com Phone: 554184001889
} 
species, has been used with peach palm (Bactris gasipaes) by Steinmacher et al. (2007c) and oil palm (Elaeis guineensis), with leaf explants (Scherwinski-Pereira et al. 2010) and immature inflorescences (Guedes et al. 2011).

Somatic embryogenesis was described for A. aculeata using zygotic embryos as explants, but few of the resulting somatic embryos were capable of converting into plants (Moura et al. 2009). To our knowledge, no other sources of explants have been used for this species, so new protocols of somatic embryogenesis need to be investigated. Furthermore, TCL holds promise to achieve the goal of cloning adults of this plant.

Therefore, the aim of this work was to establish a protocol for somatic embryogenesis for A. aculeata by applying the thin cell layer technique to leaf explants of in vitro cultured plants.

\section{Material and Methods}

\section{Plant material and in vitro germination}

Mature fruits were collected at Bodoquena, Mato Grosso do Sul, Brazil (20 32'13.7'S, 56 $\left.42^{\prime} 47.7^{\prime \prime} \mathrm{W}\right)$. The endocarp was removed and the kernels were surface-sterilized under aseptic conditions by a one-minute immersion in $70 \%$ ethanol followed by a 15 minute immersion in $6 \%$ sodium hypochlorite solution with one drop of Tween $20^{\circ}$ per $100 \mathrm{ml}$ $(0.1 \%)$. The kernels were then rinsed three times in sterile distilled water. Zygotic embryos were aseptically removed from the kernels and cultured in test tubes containing 10 $\mathrm{ml}$ of germination medium with Y3 salts (Eeuweens 1976), supplemented with Morel vitamins (Morel \& Wetmore 1951), $30 \mathrm{~g} \mathrm{~L}^{-1}$ sucrose and $1 \mathrm{~g} \mathrm{~L}^{-1}$ activated charcoal and gellified with $5.8 \mathrm{~g} \mathrm{~L}^{-1}$ agar (Vetec $)$. The cultures were kept in the dark at $25 \pm 2{ }^{\circ} \mathrm{C}$ for 4 weeks and then under coolwhite fluorescent tubes with a photosynthetic photon flux density (PPFD) of $40 \mu \mathrm{mol} \mathrm{m}^{-2} \mathrm{~s}^{-1}$ and a $16 \mathrm{~h}$ photoperiod for eight weeks.

Twelve-week old seedlings of $2-4 \mathrm{~cm}$ had their roots, cotyledonary petioles and most external leaves removed. The remaining leaf portion was transversally cut from the base into eight slices about one mm thick (TCLs) (Steinmacher et al. 2007c), which were used as explants for somatic embryogenesis (Fig. 1). The first explant was composed of leaf sheath and apical meristem and the others of leaf fragments; the original position of the explants was maintained in the Petri dish during their culture.

\section{Callogenesis and induction of somatic embryogenesis}

The effect of three picloram concentrations $(150,300$ and $600 \mu \mathrm{M}$ ) and of the initial explant position on primary callus formation were studied. TCL explants were inoculated in glass Petri dishes $(10 \times 2 \mathrm{~cm})$ containing $40 \mathrm{ml}$ of culture medium and sealed with plastic film. The induction medium

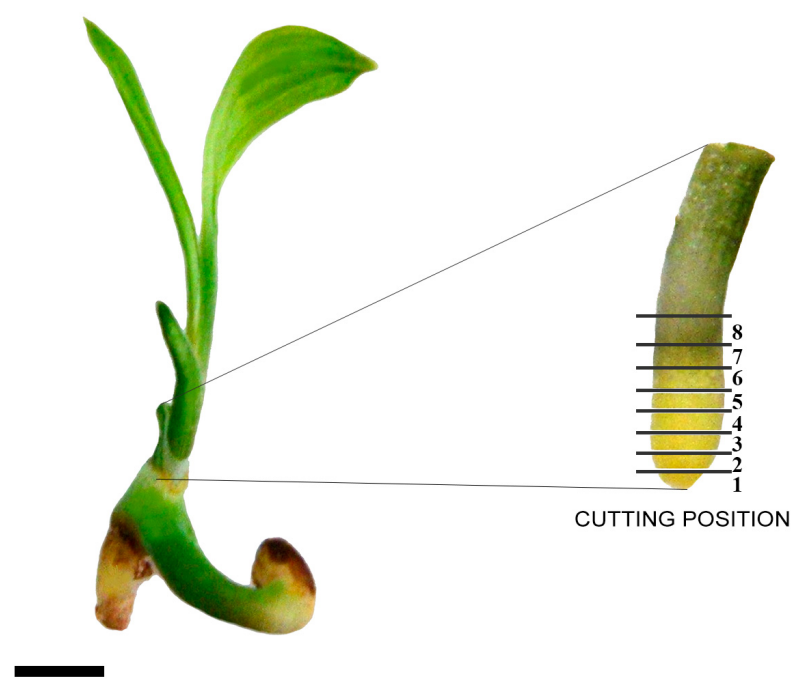

Figure 1. Schematic figure showing the location of explant origin in the leaf region (magnification) of Acrocomia aculeata seedlings. The black lines represent the location of cuts for the eight slices used in the experiments (dark bar $=5.6 \mathrm{~mm}$ ).

contained Y3 salts, Morel vitamins, $30 \mathrm{~g} \mathrm{~L}^{-1}$ sucrose, $1.5 \mathrm{~g} \mathrm{~L}^{-1}$ activated charcoal, $2 \mathrm{~g} \mathrm{~L}^{-1}$ Gelzan (Sigma), $500 \mathrm{mg} \mathrm{L}^{-1}$ glutamine and 150, 300 or $600 \mu \mathrm{M}$ picloram. The explants were cultured in the dark, as described above, for 12 weeks. No subculture was applied. Callus formation was evaluated after 12 weeks.

The primary calli obtained in the media with 150 or 300 $\mu \mathrm{M}$ picloram were transferred to a multiplication medium. In this step, the medium described above was used except that the activated charcoal concentration was reduced to $0.3 \mathrm{~g} \mathrm{~L}^{-1}, 75 \mu \mathrm{M}$ picloram, and $500 \mathrm{mg} \mathrm{L}^{-1}$ hydrolyzed casein were added. The treatments consisted of the addition of 2-iP or BAP to this medium ( 12.5 or $25 \mu \mathrm{M}$ of each, separately). Subcultures on the same fresh culture medium were carried out at 4 -week intervals for 8 weeks. Calli were classified into three morphological types: compact, nodular and friable. The nodular calli with embryogenic clusters were transferred to a maturation medium containing Y3 salts, Morel vitamins, $30 \mathrm{~g} \mathrm{~L}^{-1}$ sucrose, $2 \mathrm{~g} \mathrm{~L}^{-1}$ Gelzan (Sigma), $1 \mathrm{~g} \mathrm{~L}^{-1}$ glutamine, $0.5 \mu \mathrm{M}$ NAA and BAP or 2 -iP (12.5 or 25 $\mu \mathrm{M}$ of each, separately) for 4 weeks under light and then to a conversion medium (same as the germination medium described above) where they were maintained under light for eight weeks.

\section{Histological analysis}

In order to observe the origin and development of the callus and the somatic embryos, histological analysis was performed throughout the steps of somatic embryogenesis. The second slice from the base was collected for anatomical study at zero, two, five, seven, 15 and 30 days after culture. Samples were fixed in a Karnovsky's solution (Karnovsky 
1965), dehydrated in a graded ethanol series and embedded in Leica Historesin (Leica Microsystem) following the manufacturer's instructions. Using a rotary microtome, 5-7 $\mu \mathrm{m}$ sections were acquired, mounted on a slide, and stained with toluidine blue in $0.1 \mathrm{M}$ phosphate buffer, $\mathrm{pH}$ 6.8 (O'Brien et al. 1964).

\section{Experimental design and statistical analyses}

The experiment comparing the effect of picloram concentration and explant origin incorporated a completely randomized design with five repetitions. Each repetition was composed of four Petri dishes with eight explants of the same plant in each. Callus induction percentage was evaluated after 90 days. The experiment comparing BAP and 2-iP employed a completely randomized design with 10 repetitions. Each repetition was composed of one Petri dish with five primary calli. Callus consistency was evaluated at this step. For the maturation experiment, five repetitions of a Petri dish with five nodular calli were used. The number of somatic embryos and the number of converted somatic embryos were counted. These experiments were repeated twice and the mean for each was used. Data were transformed to achieve homogeneity of variances and then submitted to analysis of variance (ANOVA). Means were compared using Tukey's multiple range test at $5 \%$ significance.

\section{Results}

Callus formation began after two weeks in the induction medium, mainly in the basal explants. After 12 weeks, significant differences were observed between the picloram concentrations, with the best results being obtained with 150 and $300 \mu \mathrm{M}$ picloram (Fig. 2). Concerning the explant

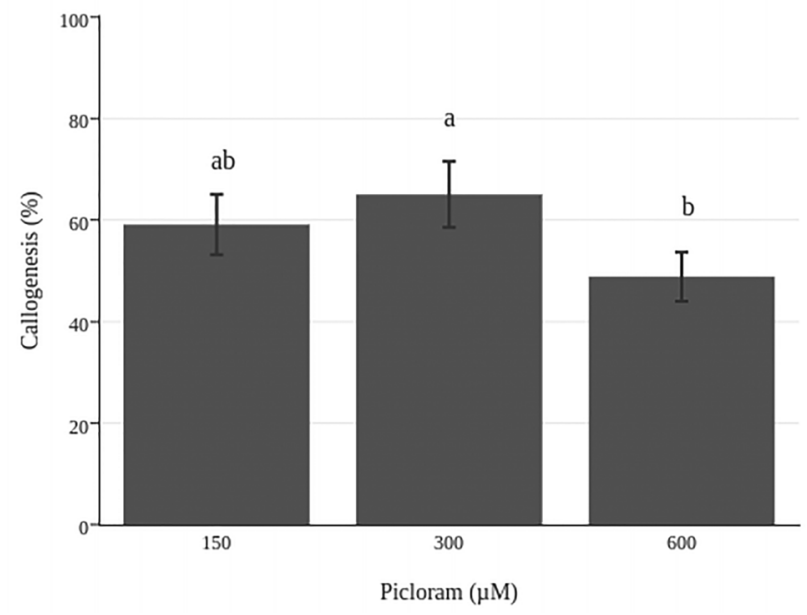

Figure 2. Effect of picloram concentration on primary calli formation in TCLs from leaves of Acrocomia aculeata after 12 weeks of culture. Letters represent significant differences among the picloram concentrations according to Tukey's test at 5\% significance. Vertical bars represent standard errors of the mean. position, the basal TCLs had high rates of callogenesis, and the first three TCLs had the highest percentages (Fig. 3). The primary calli were compact and had a whitish to yellowish color.

In the multiplication medium the primary calli increased in volume and after 16 weeks three morphological types of calli could be characterized: compact, yellowish to brown, hard, and non-embryogenic calli (Fig. 4A); friable, whitish to yellowish, soft and non-embryogenic calli (Fig. 4B); and nodular, whitish and embryogenic calli with semi-compact texture and with embryogenic masses (Fig. 4C). There was no difference between the callus types when a cytokinin was added to the medium (Tab. 1). However, after eight weeks in the multiplication medium, embryogenic clusters were observed on nodular calli. These calli were then transferred to the maturation medium and pro-embryos formed (Fig. 4D-E). The number of calli with somatic embryos was low (24\%), but in media supplemented with the low cytokinin concentration $(12.5 \mu \mathrm{M})$ more somatic embryos appeared, with an average of 38 per nodular callus on medium containing 2-iP and 25 per nodular callus on medium with BAP. In the presence of the highest concentration of 2-iP and BAP $(25 \mu \mathrm{M})$, five and four somatic embryos per nodular callus appeared, respectively.

When the somatic embryos were transferred to the conversion medium, a few of them (18\%) became green and converted into plants (Fig. 4F-G). Other somatic embryos became dark and did not fully complete their development (Fig. 4H). The converted embryos did not survive acclimatization.

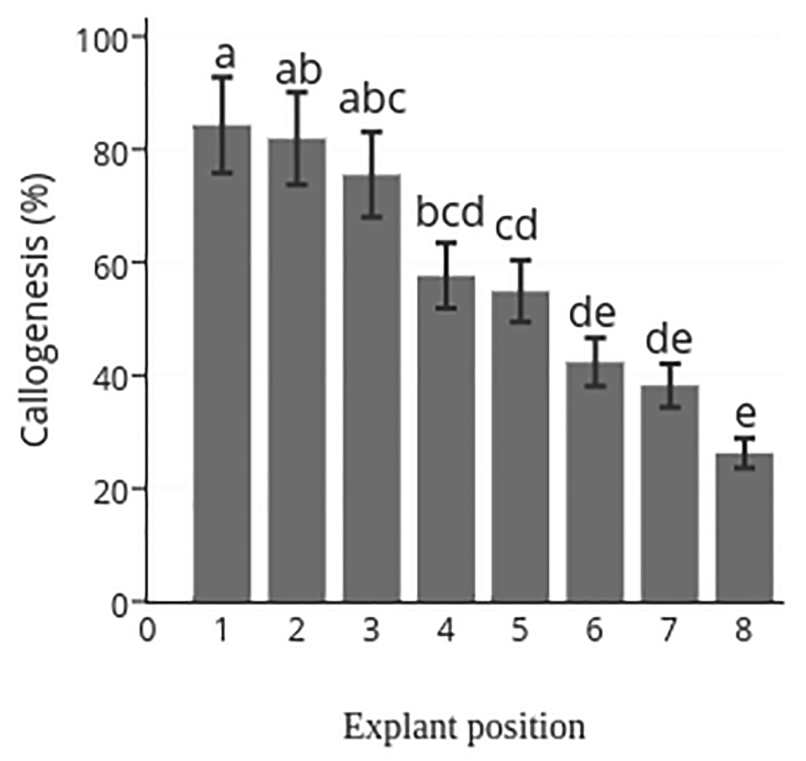

Figure 3. Effect of explant origin on primary calli formation in TCLs from leaves of Acrocomia aculeata after 12 weeks of culture. The most basal TCL is numbered 1 and the most apical is numbered 8. Letters represent significant differences among explants according to Tukey's test at 5\% significance. Vertical bars represent standard errors of the mean. 

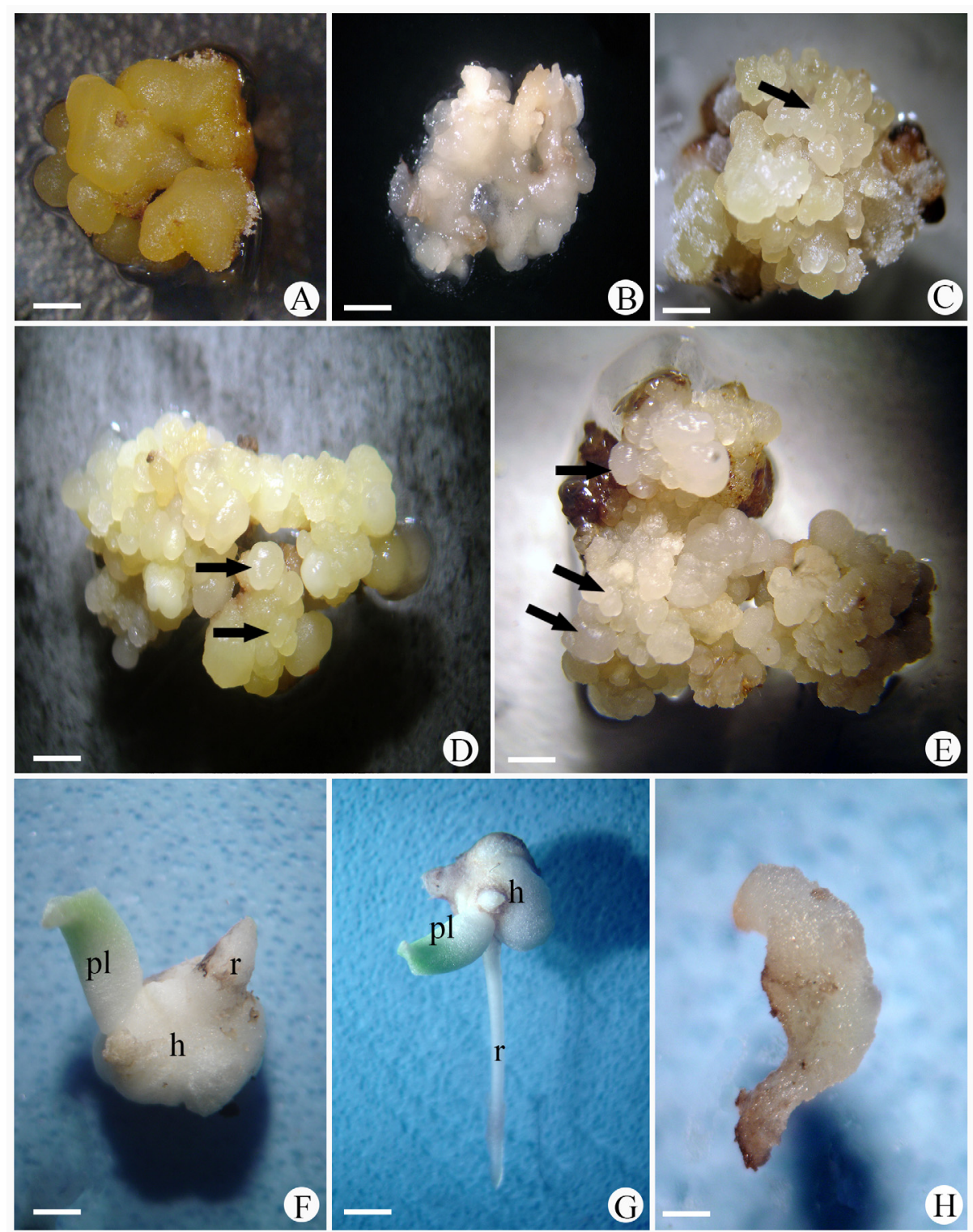

Figure 4. Morphology of somatic embryogenesis in Acrocomia aculeata. A. Appearance of a compact, yellowish, non-embryogenic callus after 16 weeks of in vitro culture $(\mathrm{bar}=5.2 \mathrm{~mm}$ ). B. Appearance of a friable, non-embryogenic callus after 16 weeks of in vitro culture. Note the mucilaginous appearance $($ bar $=5.1 \mathrm{~mm})$. C. Appearance of a nodular, semi-compact, callus with an embryogenic mass on its surface (arrow) after 16 weeks of in vitro culture (bar $=4.6 \mathrm{~mm}$ ). D. Nodular callus showing proembryo formation (arrows) after 20 weeks of in vitro culture (bar $=2.8 \mathrm{~mm}$ ). E. Somatic embryo cluster with well-formed globular embryos (arrows) after 4 weeks in maturation conditions $(\mathrm{bar}=3.7 \mathrm{~mm}$ ). F. Somatic embryo conversion with plumule and radicle emission and haustorium formation in conversion medium after 26 weeks of in vitro culture $(\mathrm{bar}=1.9 \mathrm{~mm})$. G. Regenerated plantlet with root and plumule after 30 weeks of in vitro culture (bar=2.4 mm). H. Malformed somatic embryo conversion, which formed neither leaves nor roots after 30 weeks of in vitro culture (bar= $2 \mathrm{~mm}$ ). $\mathbf{p l}=\mathbf{p l u m u l e}, \mathbf{r}=\mathbf{r a d i c l e}, \mathbf{h}=$ haustorium. Please see the PDF version for color reference.

Table 1. Effect of combinations of picloram and 2-iP or BAP on consistency of callus developed from TCLs of Acrocomia aculeata leaves after four weeks of culture in multiplication medium.

\begin{tabular}{ccccc}
\hline \multirow{2}{*}{ Picloram $(\mu \mathrm{M})$} & $2-\mathrm{iP}(\mu \mathrm{M})$ & BAP $(\mu \mathrm{M})$ & \multicolumn{2}{c}{ Callus consistency } \\
\cline { 4 - 5 } 75 & 12.5 & 0 & $53.8 \mathrm{~ns}$ & Compact $(\%)$ \\
75 & 25 & 0 & $31.8 \mathrm{~ns}$ & $46.1 \mathrm{~ns}$ \\
75 & 0 & 12.5 & $41.4 \mathrm{~ns}$ & $68.2 \mathrm{~ns}$ \\
75 & 0 & 25 & $52.1 \mathrm{~ns}$ & $58.6 \mathrm{~ns}$ \\
\hline
\end{tabular}

ns = not significant according to Tukey's test at $5 \%$ significance. 


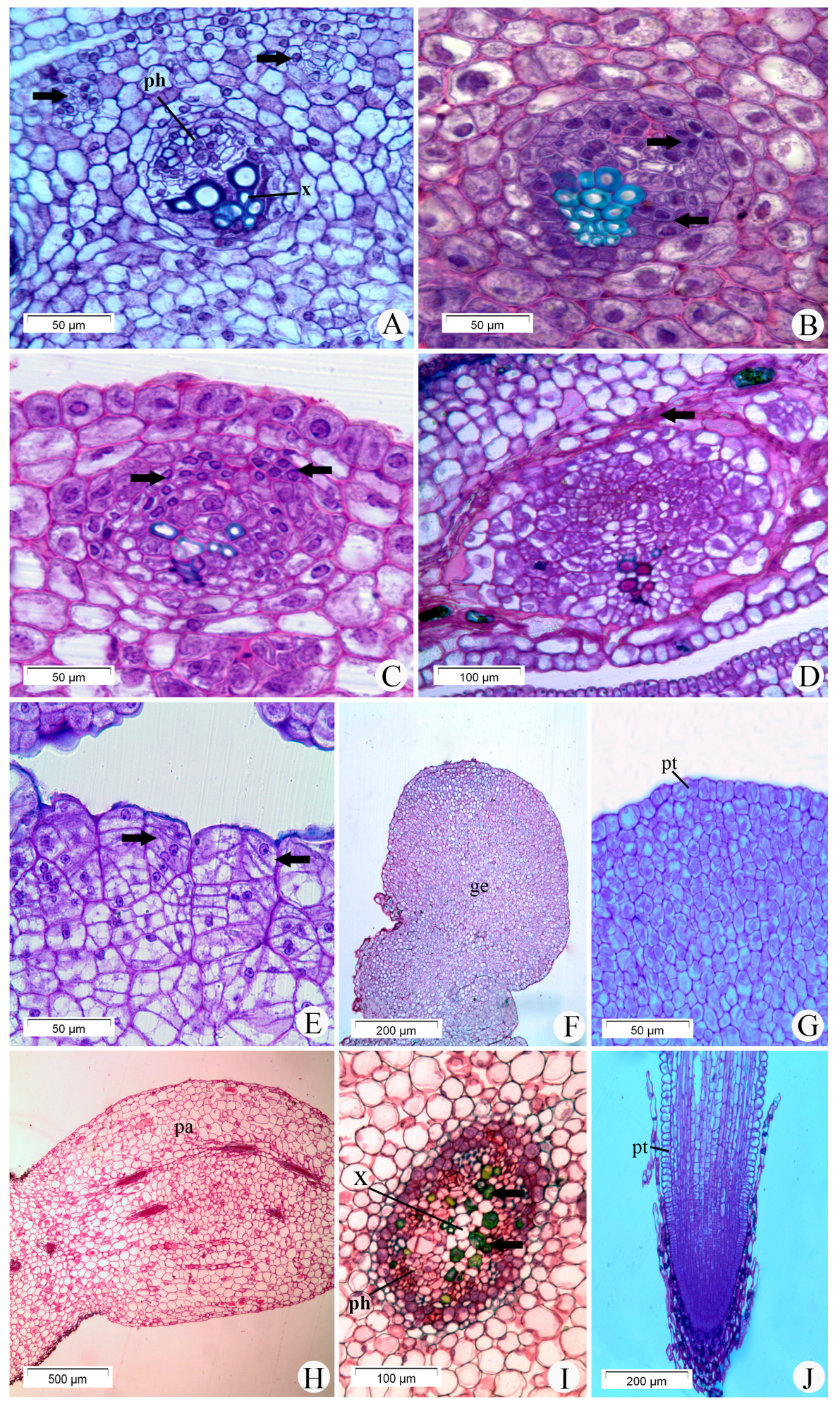

Figure 5. Histology of somatic embryogenesis of leaf explants of Acrocomia aculeata. A Basal transverse section (the second TCL) of a leaf prior to in vitro culture, showing major vascular bundles with differentiated xylem (x) and phloem (ph), and minor bundles (arrows). B Second TCL transverse section after 2 days of in vitro culture showing new small cells, with large nuclei and dense cytoplasm, in perivascular parenchyma (arrows). C Second TCL transverse section after 5 days of in vitro culture showing cell groups with meristematic characteristics (arrows). D Second TCL transverse section after two weeks of in vitro culture showing callus formation and compressed parenchymatous cells (arrow). E Somatic embryo initiation on peripheral cells of a nodular callus (arrows) after 18 weeks of in vitro culture. F Globular embryo (ge) with differentiated protoderm after 24 weeks of in vitro culture. G Detail of protoderm (pt) in a globular embryo after 24 weeks of in vitro culture. $\mathbf{H}$ Longitudinal section of plumule in converted seedling showing malformed protoderm and a loose parenchyma after 30 weeks of in vitro culture. I Transverse section of plumule in converted seedling showing a vascular bundle with phenolic compounds (arrow). J Longitudinal section of radicle in converted seedling after 30 weeks of culture showing protoderm. $\mathbf{p h}=$ phloem, $\mathbf{x}=\mathbf{x y l e m}$, ge=globular embryo, $\mathbf{p t}=$ protoderm, $\mathbf{p a}=$ parenchyma. 


\section{Histological analyses}

The histological analyses of basal TCLs were performed prior to their culture showing several collateral vascular bundles distributed along the tissue. Major vascular bundles with differentiated xylem and phloem, and minor bundles in differentiation, were identified (Fig. 5A). After two days of in vitro culture there was an increase in the number of cells in the perivascular parenchyma (Fig. 5B). These new cells were smaller in diameter, and had a larger nucleus and denser cytoplasm than the older cells. After five days, groups of meristematic cells with collapsed sieve tubes appeared in the perivascular parenchyma, mainly among the disorganized cells near the phloem (Fig. 5C). After 15 days, small meristematic isodiametric cells showed periclinal and anticlinal divisions, indicating radial growth, which compressed the parenchymatous cells of the explant (Fig. 5D).

Within 12 weeks, nodular calli appeared on some primary calli, with a higher cell division rate in the peripheral cells. After 18 weeks of culture, globular structures appeared to arise from the peripheral cells of nodular calli (Fig. 5E). Somatic embryos showed a well formed protoderm and some appeared fused together after 24 weeks (Fig. 5F-G). Phenolic compounds were present in some protodermic cells and somatic embryos with a discontinuous protoderm were observed. The few converted embryos showed a malformed protoderm and a loose parenchyma (Fig. 5H-I). The vascular bundles of converted plantlets showed some cells with phenolic compounds (Fig. 5I) and the radicle showed malformed protoderm (Fig. 5J).

\section{Discussion}

The TCL technique, first developed by Tran Thanh Van (1973), proved efficient at inducing callus formation from sections of leaves of A. aculeata, and producing somatic embryos. However, difficulties in conversion were encountered, as also reported by Moura et al. (2009) for somatic embryogenesis from zygotic embryos. A preliminary experiment with this species found that callus induction in leaf explants of a $5 \mathrm{~mm}$ thickness was very low (data not shown), while the induction in transverse TCLs was high.

The advantage of TCL is that cells have greater contact with the nutrients and growth regulators present in the culture medium than do whole explants (Ahn et al. 1996). Furthermore, TCL provides a simple and efficient system of micropropagation that can be used in the propagation of elite clonal plants (Monja-Mio \& Robert 2013). In addition to A. aculeata, the TCL technique has been used with success in Bactris gasipaes (Steinmacher et al. 2007c) and in Elaeis guineensis (Scherwinski-Pereira et al. 2010). In both cases, the initial explants were leaf transverse TCLs of in-vitro grown seedlings.

In the present study, the highest rate of callus induction for A. aculeata was observed in basal explants, corresponding to apical meristems with cells in division and differentiation. Leaf explants react according to their physiological age and ontogenesis. Furthermore, in monocots, the cells most capable of callogenesis are located in young leaves (Jullien \& Tran Thanh Van 1994). In different wheat varieties, the basal portion of young leaves showed better organogenesis than that of old leaves (Mahalakshmi et al. 2003). In peach palm (Bactris gasipaes), the highest primary callus induction rate was observed in explants originating from near the apical meristem, regardless of the picloram concentration used (Steinmacher et al. 2007c). In oil palm, leaf TCLs had the highest rate of embryogenic callus and somatic embryo formation (Scherwinski-Pereira et al. 2010).

The present study confirms that picloram is necessary for callus induction in leaf explants of A. aculeata. In a preliminary experiment, the callus induction rate in leaf transverse TCLs of $A$. aculeata cultured in the presence of 2,4-D was almost nil. In the study of Moura et al. (2009) on A. aculeata, embryogenic callus formation did occur in the presence of 2,4-D and picloram, however, somatic embryo induction occurred in calli from zygotic embryos only when picloram was used. Among the synthetic auxins, picloram was also effective in inducing somatic embryogenesis in peach palm (Steinmacher et al. 2007a; b; c), oil palm (Scherwinski-Pereira et al. 2010; Silva et al. 2012), açai palm (Scherwinski-Pereira et al. 2012) and Areca catechu (Karun et al. 2004).

A high auxin concentration in association with activated charcoal has been widely used in the induction of somatic embryogenesis of palm species (Pérez-Nuñez et al. 2006; Saénz et al. 2006; Steinmacher et al. 2007b; c; Othmani et al. 2009; Perera et al. 2009; Al-Khayri 2010). For A. aculeata, Moura et al. (2009) showed that activated charcoal was essential for avoiding tissue browning and stimulating somatic embryo formation.

The transfer of primary calli of $A$. aculeata to a medium supplemented with a half-concentration of picloram and $\mathrm{BAP}$ or 2-iP, and with a reduced concentration of activated charcoal, stimulated callus growth and differentiation. Cytokinins have been used in embryogenic callus and somatic embryo induction, alone or combined with low concentrations of auxins (Rao \& Ganapathi 1993). They act on cell division and in vitro morphogenesis, regulating tissue division and differentiation (Fehér et al. 2003).

Although the induction of somatic embryogenesis was successful, very few converted into plants after being transfered to a conversion medium under light. Low conversion rate is a recurrent problem in somatic embryogenesis protocols. Despite a high somatic embryo production, the lack or low frequency of conversion into plants has been observed for many protocols (Gaj 2004). This low somatic embryo conversion rate could be associated with morphological abnormalities or embryo immaturity (Ammirato 1987; Suhasini et al. 1996). A protocol using A. aculeata zygotic embryos as starting explants, and a high sucrose concentra- 
tion in the maturation medium, improved somatic embryo regeneration (Luis \& Scherwinski-Pereira 2014).

The histological analyses performed during $A$. aculeata callogenesis showed that cellular alterations in the TCLs started after two days of in vitro culture and occurred in cells located between the bundles of xylem and phloem. In Phoenix dactilyfera, leaf explants showed cellular alterations in the fascicular parenchyma after two days of in vitro culture in the presence of NAA (Gueye et al. 2009b) or 2,4-D (Gueye et al. 2009a). In leaf TCLs of Bactris gasipaes cultured in the presence of picloram, Steinmacher et al. (2007c) observed the first cell divisions after 30 days located near vascular bundles. According to Almeida et al. (2012), the pre-procambial cells are the region of the formation of precursor cells for shoots and somatic embryos in Bactris gasipaes.

The $A$. aculeata proembryos developed in the periphery of nodular calli, as is the case for potato (Sharma \& Millan 2004). In zygotic embryos, somatic embryos formed close to procambial strands of calli and had two origins: unicellular and multicellular. In multicellular origin, somatic embryos are histologically fused with the mother tissue and could also fuse with other somatic embryos (Moura et al. 2008). This process of origin was most frequent in A. aculeata, but these embryos did not regenerate plants (Moura et al. 2008). In the present study, somatic embryos showed the same multicellular origin, which could explain the low conversion rate.

Somatic embryos showed malformations, such as an irregular epidermis, loose parenchyma or the presence of phenolic compounds in vascular cells, which may have prevented the somatic embryo from developing and differentiating. Additionally, Moura et al. (2010) found that somatic embryos had no proteins or lipids as storage compounds, which may be essential for conversion. Few somatic embryos progressed and failures occurred during their conversion into a plant, such as the failure of leaf primordium, or roots or both to develop or differentiate. The initial stages of somatic embryogenesis are crucial processes because polarity is established and protoderm and other meristems are formed. The survival and growth of regenerated plantlets depend on these factors (Bozhkov et al. 2002). Morphological alterations of somatic embryos, such as histodifferentiation, structural or functional failure of the shoot apical meristem (Nickle \& Yeung 1993; Wetzstein \& Baker 1993) and shoot apical meristem degeneration (Yeung et al. 1995) can explain the difficulty of plantlet regeneration.

In summary, this study shows that somatic embryos of A.aculeata can be obtained by the thin cell layer technique, but few somatic embryos converted into plants. This protocol can be used for future cloning of adult plants using immature leaves as starting explants, but more studies are needed and new experiments must be carried out in order to improve the conversion rate and to obtain healthy plants.

\section{Acknowledgements}

The authors thank the Coordenação de Aperfeiçoamento de Pessoal do Nível Superior - CAPES and Conselho Nacional de Desenvolvimento Científico e Tecnológico - CNPq for financial support for the development of this study.

\section{References}

Ahn IO, Le BV, Gendy C, Tran Thanh Van K. 1996. Direct somatic embryogenesis through thin cell layer culture in Panax ginseng. Plant Cell, Tissue and Organ Culture 45: 237-243.

Al-Khayri JM. 2010. Somatic embryogenesis of date palm (Phoenix dactylifera L.) improved by coconut water. Biotechnology 9: 477-484.

Almeida M, Graner EM, Almeida CV, Brondani GE, Abreu-Tarazi MF. 2012. Pre-procambial cells are niches for pluripotent and totipotent stem-like cells for organogenesis and somatic embryogenesis in peach palm: a histological study. Plant Cell Reports 31: 1495-1515.

Ammirato PV. 1983. Embryogenesis In: Evans DA, Sharp WR, Ammirato PV, Yamada Y. (eds.) Handbook of Plant Cell Culture. New York, MacMillan Publishing Co. 1: 82-123.

Ammirato PV. 1987. Organization events during somatic embryogenesis. Plant Cell, Tissue and Organ Culture 3: 57-81.

Arnold S, Sabala I, Bozhkov P, Dyachok J, Filinova L. 2002. Developmental pathways of somatic embryogenesis. Plant Cell, Tissue and Organ Culture 69: 233-249.

Belén-Camacho DR, López I, García D, et al. 2005. Evaluación físicoquímica de la semilla y del aceite de corozo (A. aculeata Jacq.). Grasas y Aceites 56: 311-316.

Bozhkov PV, Filinova LH, Arnold S. 2002. A key developmental switch during the Norway spruce somatic embryogenesis is induced by withdrawal of growth regulators and is associated with cell death and extracellular acidification. Biotechnology and Bioengineering 77: 658-667.

Cangahuala-Inocente GC, Steiner N, Santos M, Guerra MP. 2004. Morphohistological analysis and histochemistry of Feijoa sellowiana somatic embryogenesis. Protoplasma 224: 33-40.

Eeuweens CJ. 1976. Mineral requirements for growth and callus initiation of tissue explants excised from mature coconut palms (Cocos nucifera L.) and culture in vitro. Physiologia Plantarum 36: 23-28.

Fehér A, Pasternak TP, Dudits D. 2003. Transition of somatic plant cells to an embryogenic state. Plant Cell, Tissue and Organ Culture 74: 201-228.

Gaj MD. 2004. Factors influencing somatic embryogenesis induction and plant regeneration with particular reference to Arabidopsis thaliana (L.) Heynh. Plant Growth Regulators 43: 27-47.

Guedes RS, Silva TL, Luis ZG, Scherwinski-Pereira JE. 2011. Initial requirements for embryogenic calluses initiation in thin cell layers explants from immature female oil palm inflorescences. African Journal of Biotechnology 10: 10774-10780.

Gueye B, Morcillo F, Collin M, et al. 2009a. Acquisition of callogenic capacity in date palm leaf tissues in response to 2,4-D treatment. Plant Cell, Tissue and Organ Culture 99: 35-45.

Gueye B, Sane SD, Ahmed D, et al. 2009b. Callogenesis and rhizogenesis in date palm leaf segments: are there similarities between the two auxininduced pathways? Plant Cell, Tissue and Organ Culture 98: 47-58.

Henderson A, Galeano G, Bernal R. 1995. Field Guide to the Palms of the Americas. New Jersey, Princeton University Press.

Hernández C, Mieres A, Niño Z, Pérez S. 2007. Efecto de la refinación física sobre el aceite de la almendra del corozo (Acrocomia aculeata). Información tecnológica 18: 59-68.

Jullien F, Tran Thanh Van K. 1994. Micropropagation and embryoid formation from young leaves of Bambusa glaucescens 'Golden goddess'. Plant Science 98: 199-207.

Karnovsky MJA. 1965. A formaldehyde-glutaraldehyde fixative of high osmolality for use in electron microscopy. The Journal of Cell Biology 27: 137-138. 
Karun A, Siril EA, Radha E, Parthasarathy VA. 2004. Somatic embryogenesis and plantlet regeneration from leaf and inflorescence explants of arecanut (Areca catechu L.). Current Science 86: 1623-1628.

Lorenzi GMAC. 2006. Acrococomia aculeata (Jacq.) Lodd. ex Mart. - Arecaceae: bases para o extrativismo sustentável. PhD Thesis, Universidade Federal do Paraná, Brazil.

Luis ZG, Scherwinski-Pereira JE. 2014. An improved protocol for somatic embryogenesis and plant regeneration in macaw palm (Acrocomia aculeata) from mature zygotic embryos. Plant Cell, Tissue and Organ Culture 118: 485-496.

Mahalakshmi A, Khurana JP, Khurana P. 2003. Rapid induction of somatic embryogenesis by 2,4-D in leaf cultures of wheat (Triticum aestivum L.). Plant Biotechnology 20: 267-273.

Monja-Mio KM, Robert ML. 2013.Direct somatic embryogenesis of Agave fourcroydes Lem. through thin cell layer culture. In Vitro Cellular \& Developmental Biology-Plant 49: 541-549.

Morel G, Wetmore RH. 1951. Tissue culture of monocotyledons. American Journal of Botany38: 138-140.

Motoike SY, Lopes FA, Sá Junior AQ, Carvalho M, Oliveira MAR. 2007. Processo de germinação e produção de sementes pré-germinadas de palmeiras do gênero Acrocomia. Patent: PI0703180-7.

Moura EF, Motoike SY, Ventrella MC, Junior AQS, Carvalho M. 2009. Somatic embryogenesis in macaw palm (Acrocomia aculeata) from zygotic embryos. Scientia Horticulturae 119: 447-454.

Moura EF, Ventrella MC, Motoike SY. 2010. Anatomy, histochemistry and ultrastructure of seed and somatic embryo of Acrocomia aculeata (Arecaceae). Scientia Agricola 67: 399-407.

Moura EF, Ventrella MC, Motoike SY, Junior AQS, Carvalho M, Manfio CE. 2008. Histological study of somatic embryogenesis induction on zygotic embryos of macaw palm (Acrocomia aculeata (Jacq.) Lodd. ex Martius). Plant Cell, Tissue and Organ Culture 95: 175-184.

Nhut DT, Silva T da, Aswath CR. 2003. The importance of the explant on regeneration in thin cell layer technology. In Vitro Cellular \& Developmental Biology-Plant 39: 266-276.

Nickle TC, Yeung EC.1993. Failure to establish a functional shoot meristem may be a cause of conversion failure in somatic embryos of Daucus carota (Apiaceae). American Journal of Botany 80: 1284-1291.

O'Brien TP, Feder N, McCully ME. 1964. Polychromatic staining of plant cell walls by toluidine blue O. Protoplasma 59: 367-373.

Othmani A, Bayoudh C, Drira N, Marrakchi M, Trifi M. 2009. Somatic embryogenesis and plant regeneration in date palm Phoenix dactylifera L., cv. Boufeggous is significantly improved by fine chopping and partial desiccation of embryogenic callus. Plant Cell, Tissue and Organ Culture 97: 71-79.

Perera PIP, Vidhanaarachchi VRM, Gunarhilake TR, et al. 2009. Effect of plant growth regulators on ovary culture of coconut (Cocos nucifera L.). Plant Cell, Tissue and Organ Culture 99: 73-81.

Pérez-Nuñez MT, Chan JL, González T, et al. 2006. Improved somatic embryogenesis from Cocos nucifera (L.) plumule explants. In Vitro Cellular \& Developmental Biology-Plant 42: 37-43.

Ramos MIL, Ramos-Filho MM, Hiane PA, Braga Neto JA, Siqueira EMA. 2008. Qualidade nutricional da polpa de bocaiúva Acrocomia aculeata (Jacq.) Lodd. Ciência e Tecnologia de Alimentos 28: 90-94.

Rao PS, Ganapathi TR. 1993. Micropropagation of palms. In: Ahuja MR. (ed.) Micropropagation of woody plants. Berlin, Springer. p. 405-421.

Ribeiro LM, Oliveira DMT, Garcia QS. 2012. Structural evaluations of zygotic embryos and seedlings of the macaw palm (Acrocomia aculeata, Arecaceae) during in vitro germination. Trees 26: 851-863.
Saénz L, Azpeitia A, Chuc-Armendariz B, et al. 2006. Morphological and histological changes during somatic embryogenesis from coconut plumule explants. In Vitro Cellular \& Developmental Biology-Plant 42: $19-25$

Sané D, Aberlenc-Bertossi F, Gamassa-Dia YK, et al. 2006. Histocytological analysis of callogenesis and somatic embryogenesis from cell suspensions of date palm (Phoenix dactylifera). Annals of Botany 98: 301-308.

Scariot AO, Lleras E, Hay JD. 1995. Flowering and fruiting phenologies of the palm Acrocomia aculeata: patterns and consequences. Biotropica 27: $168-173$

Scherwinski-Pereira JE, Guedes RS, Fermino PCP, Dilva TL, Costa FH. 2010. Somatic embryogenesis and plant regeneration in oil palm using the thin cell layer technique. In Vitro Cellular \& Developmental Biology-Plant 46: 378-385.

Scherwinski-Pereira JE, Guedes RS, Silva RA, Fermino PCP, Luis ZG, Freitas EO. 2012. Somatic embryogenesis and plant regeneration in açaí palm (Euterpe oleracea). Plant Cell, Tissue and Organ Culture 109: 501-508.

Sharma SK, Millan S. 2004. Somatic embryogenesis in Solanum tuberosum L.: a histological examination of key developmental stages. Plant Cell Reports 23: 115-119.

Silva JA. 2010. Thin Cell Layers: Power-Tool for Organogenesis of Floricultural Crops. In: Jain SM, Ochatt SJ. (eds.) Protocols for in Vitro Propagation of Ornamental Plants, Methods in Molecular Biology. New York, Humana Press, a part of Springer Science + Business Media. p. 377-391.

Silva JA, Tran Thanh Van K, Biondi S, Nhut DT, Altamura, MM. 2007. Developmental Building Blocks in Ornamental Biotechnology. Floriculture and Ornamental Biotechnology 1: 1-13.

Silva, RC, Luis ZG, Scherwinski-Pereira JE. 2012. Differential responses to somatic embryogenesis of different genotypes of Brazilian oil palm (Elaeis guineensis Jacq.), Plant Cell, Tissue and Organ Culture 111: 59-67.

Steinmacher DA, Cangahuala-Inocente GC, Clement CR, Guerra MP. 2007a. Somatic embryogenesis from peach palm zygotic embryos. In Vitro Cellular \& Developmental Biology-Plant 43: 124-132.

Steinmacher DA, Clement CR, Guerra MP. 2007b. Somatic embryogenesis from immature peach palm inflorescence explants: towards development of an efficient protocol. Plant Cell, Tissue and Organ Culture 89: $15-22$.

Steinmacher DA, Krohn NG, Dantas ACM et al. 2007c. Somatic Embryogenesis in Peach Palm Using the Thin Cell Layer Technique: Induction, Morpho-histological Aspects and AFLP Analysis of Somaclonal Variation. Annals of Botany 100: 1-11.

Suhasini K, Sagare AP, Krishnamurthy KV. 1996. Study of aberrant morphologies and lack of conversion of somatic embryos of chickpea (Cicer arietinum $\mathrm{L}$ ). In Vitro Cellular \& Developmental Biology-Plant 32: 6-10.

Tran Thanh Van KM. 1973. Direct Flower Neoformation from Superficial Tissue of Small Explants of Nicotiana tabacum L. Planta 115: 87-92.

Wetzstein HY, Baker CM. 1993. The relationship between somatic embryo morphology and conversion in peanut (Arachis hypogaea L.). Plant Science 9: 81-89.

Yeung EC.1995. Structural and developmental patterns in somatic embryogenesis. In: Bajaj YPS. (ed.) In vitro embryogenesis in plants. Dordrecht, Kluwer Academic. p. 205-248. 